Алейников А.B.

\title{
ОСОБЕННОСТИ РОССИЙСКОЙ КОНФЛИКТНОЙ МОДЕЛИ: ОСНОВАНИЯ ТЕОРЕТИЧЕСКОГО АНАЛИЗА
}

\begin{abstract}
Аннотация: Выявляются и анализируются системные характеристики и основные составляющие российских «кейсов» структурных конфликтов, драйверы и триггеры возможного разрушения российской социальной системы. Показано, что «институиионализированные стандарты» нормативной конфликтологической культуры российского общества формируются на основе глубинного архетипа «конфликтологического разума» российского народа, предопределяющего «токсично-конфликтогенный тип развития России. Значительное место уделено анализу российской специфики конфигурации системы институцио ᄀнального ограничения конфликтов. Ключевые слова: Политология, Россия, конфликт, конфликтогенность, трансформачия, модернизачия, консенсус, общество, политика, власть
\end{abstract}

$\Pi$ ротиворечивая природа трансформационных процессов в России, которые Р. Дарендорф описывал как «долгий путь через “долину слез” и “юдоль печали”», может быть осмыслена с учётом предложенного Н.Бердяевым дискурса антиномичности.

Философ утверждал, что «подойти к разгадке тайны, скрытой в душе России, можно, сразу же признав антиномичность России, жуткую ее противоречивость»l. Конечно, страсть Бердяева к парадоксам и иветистой афористичности неоднократно служили поводом к оценкам данных его воззрений как «соииологически-поверхностных». Но можно вполне согласиться с Н.С.Розовым: «За прочедшие почти сто лет, несмотря на огромную литературу на ту же тему, продвижение в сравнении с идеями Бердяева, мягко говоря, скромное»².

Напомним, что понятием «антиномия» И. Кант обозначал предельно возможные противоречия знаний, из которых ни одному нельзя отдать предпочтения перед другим, т.е. «умствующие положения, которые не могут надеяться на подтверждение опытом, но и не должны опасаться опровержения с его стороны, при этом каждое из них не только само по себе свободно от противоречий, но даже находит в природе разума условия своей необходимости; однако, к сожалению, и противоположное утверждение имеет на своей стороне столь же веские и необходимые основания» ${ }^{3}$.

\footnotetext{
${ }^{1}$ Бердяев Н.А. Судьба России.М.:АСТ,2010,С.13.

${ }^{2}$ Розов Н.С. Колея и перевал: макросоциологические основания стратегий России в XXI веке. М.: РОССПЭН, 2011,С.190

${ }^{3}$ Кант И. Критика чистого разума // Кант И. Соч. Т. 3. М.: Мысль, 1964,С.400
}

Перенос Бердяевым понятия «антиномия» из сферы идей в сферу общества означает обнаружение таких противоречивых свойств социума, которые, постоянно переходя друг в друга, неустранимы.

В сентенциях Бердяева несколько смысловых центров. Во-первых, он указывает, что антиномичность прослеживается во всех проявлениях бытия России: Во-вторых, он обращает наше внимание на то, что, неустранимость противоречий относится и к попыткам осознания антиномичности русского социума, когда «разум, попавший в момент своих величайших ожиданий в тиски противоположных доводов, чувствует себя в высшей степени стесненным» ${ }^{4}$. В-третьих, он признает, что на вопрос: «Как понять эту загадочную противоречивость России, эту одинаковую верность взаимоисключающих в ней тезисов» - никто не дал удовлетворительного ответа.

Наблюдения Бердяева можно и нужно резко усилить - эта антиномичность «не разрешима, а лишь феноменально (классово, социально, экономически, технологически, идеологически) преобразуема» ${ }^{5}$.

Зафиксировав выделенные системообразующие признаки антиномичной дилеммы как такого типа противоречий, где каждая из противоположностей имеет одинаково прочные базовые основания в реальности, а контрнаправленные тенденции не поддаются снятию и воспроизводятся, можно, по-нашему мнению, операционализировать понятие «конфликтологический генотип». Это устойчивый, самовоспроизводя-

\footnotetext{
${ }^{4}$ Кант И. Указ.соч.,С.433.

${ }^{5}$ Кантор К.M., Двойная спираль истории: Историософия проектизма. Т.1: Общие проблемы. М.: Языки славянской культуры,2002,С.95
} 
щийся в историческом времени комплекс социальных структур (отношений, организаций и институтов), совокупность закономерностей историко-конфликтной генетики, специфический стержень, определяющий национальную специфику конфликта, поведения в нем социальных субъектов и методов его регулирования. Суть «конфликтологического генотипа» - в передаче от поколения к поколению главных черт, стереотипов конфликтного восприятия социальной действительности, допустимых рамок развития конфликтов, закрепленных в обычаях предпочтительных способов и методов их разрешения, определенный уровень навыков поведения в конфликте.

В историософии Карла Кантора-это паттерны, «геноподобные активные, устойчивые элементы социокультуры, определяющие ее наследственность и изменчивость, многообразие типов социокультур, процессы их роста, развития, их конвергенции и дивергенции, их кроссинговеры и мутации» ${ }^{6}$.

Допустимо, на наш взгляд, используя данную методологию, говорить и о «конфликтогенном паттернальном ансамбле», российская конфигурация которого определяется тем, что «не только индивид зависит от общества, но и общество начинает зависеть от индивида, причем уже не как от своей определенной функции или как от статистической единицы, а как от носителя непредусмотренного обществом своеобразия простых или сложных форм жизненного опыта. Вот тут и возникает вполне выраженный конфликт между обществом и индивидом. Общество при всех столкновениях с индивидом обычно берет верх. Но оно уже не может полностью игнорировать не предопределенные им особенности индивидов: оно в них нуждается... Конфликт между индивидом и обществом в этом типе не столько внешний, сколько внутренний - в сознании самого индивида. В сознании своем он и отличен от общества и его культуры, и еще всецело принадлежит им. Самую свою способность создать нечто выходящее за пределы существующих ценностей, знаний и норм индивид оправдывает своей уверенностью, что в конце концов это нужно будет обществу - обществу, а не ему самому... Общественное непризнание индивидуального своеобразия может оказаться роковым для индивида этого типа в двояком смысле - его либо постигнут кары общества, либо он сам осудит себя: сникнет,

\footnotetext{
${ }^{6}$ Там же, C.70.
}

опустится социально или наложит на себя руки. Индивид такого типа не живет для себя и, вместе с тем, иначе как «для себя» жить не может. Это мучительное противоречие сознания очень труднопреодолимо, если преодолимо вообще» ${ }^{7}$.

Рассматривая дуализм как действительно конститутивную черту российского социума, Кантор акцентирует внимание на его чрезмерности, перехлестывании через край, гипертрофированности. «Если это государство, то более могущественное, чем это необходимо для жизнедеятельности общества, то есть чрезмерное. Если это личность, то неуемная, не свободная, а анархическая, не ограниченная ничем, кроме собственного произвола и в щедрости, и в разгуле, и в насилии над собой и другими, то есть тоже чрезмерная» ${ }^{8}$.

Подчеркнем - в негативном взаимодействии социальных субъектов в «конфликтогенном паттернальном ансамбле» России важно то, что взаимодействуют не крайности, а чрезмерности. «Крайности сходятся, чрезмерности - никогда. Они противоборствуют, взаимопревращаются и снова возрождаются к новой и не имеющей исхода борьбе» ${ }^{9}$.

Эту ситуацию очень ясно диагностировал на материалах послереволюционной России В.П.Булдаков: «Практически не осталось людей, живущих в гармонии со своим социальным окружением и давлением "внешнего мира". Противоречия носили настолько сложный, системно-парализующий характер, что возник синдром “гордиева узла",который проще разрубить, чем распутать... Эти фрустрационные судороги... сказываются и сегодня» ${ }^{10}$. Актуальность подобного конструкта подтверждает и другой авторитет: «Российское общество в 1861-1914 г.г. развивалось «по сценарию, как будто специально написанному для него теорией социального конфликта, - конфликт стал неотъемлемой частью общественной жизни, а вражда различных социальных групп, борьба за групповые интересы, насилие ради их достижения - нормой» ${ }^{11}$. Естественно, что хронологические рамки данного сценария гораздо шире.

\footnotetext{
${ }^{7}$ Там же, C.77

${ }^{8}$ Там же,С.93

9 Там же,С.93-94

${ }^{10}$ Булдаков В.П. Утопия, агрессия, власть. Психосоциальная динамика постреволюционного времени. Россия, 19201930гг. М.:РОССПЗН, 2012, С.732

${ }^{11}$ Миронов Б.Н. Русские революции начала XX века: уроки для настоящего // Полис. 2011. №5. С. 37.
} 


\section{Политика и общество 6 (102) • 2013}

В глобальном индексе миролюбия ${ }^{12}$ (Global Peace Index), Россия занимает 153 место из 158 между Корейской Народно-Демократической Республикой и Демократической Республикой Конго. Т.Парсонс утверждал, что именно ценностно-нормативный консенсус в обществе обеспечивает социальный порядок, а максимальное распространение не находящихся в конфликтных отношениях, потенциально примиряемых базовых ценностей и норм, их институционализация обеспечивает стабильность и четкое функционирование общества ${ }^{13}$. В сравнительном же исследовании ценностей, проводимом В.Магуном и М.Рудневым по методике Ш. Шварца, было показано, что по параметрам «благожелательность» и «универсализм» (приятие чужого) Россия среди европейских стран стоит на одном из последних мест и принадлежит к числу европейских стран с низким межиндивидуальным ценностным консенсусом по большинству базовых ценностей ${ }^{14}$.

Данная симптоматика определяет значимость исследования российских «кейсов» системных конфликтов модернизационных рисков глобального мира «текучей современности» (3. Бауман) в силу того, что сегодня необходимо представлять драйверы и триггеры ${ }^{15}$ возможного разрушения российской системы. Ключевым в данном контексте представляется анализ тенденций повторения определенных институциональных схем и исторических истоков трудностей имплантации модернизационных проектов в России.

${ }^{12}$ Глобальный индекс миролюбия определяется агрегированием 23 показателей, объединенных в три основные группы: наличие и масштабы внутренних и международных конфликтов, в которых участвует государство; уровень стабильности и безопасности внутри государства; уровень милитаризации государства и оценивается по шкале от 1 (максимальное миролюбие) до 5 (минимальное миролюбие). Для постсоветской России индекс миролюбия в 2012 году составил 2,938 . Первое место по миролюбию (индекс 1,113 ) заняла Исландия, а последнее (индекс3,392) - Сомали. См.: Нисневич Ю.А.Постсоветская Россия: двадцать лет спустя.//Полис,2013,№1.

13 Парсонс T. О социальных системах. М.: Академический проект, 2002.

14 Вестник общественного мнения, 2008, №;1, СС. 33-58; Вестник общественного мнения,2011,№;4,СС.81-97.

${ }^{15}$ Мельвиль Ю.А.,Тимофеев И.Н. 2020: российские альтернативы revisited// Полития: Анализ. Хроника. Прогноз, 2010. № 2. C. $42-65$
Соответственно, главным для нашего анализа являются те, по формуле Т. Парсонса, «институционализированные стандарты» ${ }^{16}$ нормативной конфликтологической культуры российского общества и глубинного архетипа «конфликтологического разума» российского народа, которые влияют на « токсично-конфликтогенный» ${ }^{17}$ тип российских социальных форм.

Российская трансформационная модель является, говоря словами Дугласа Норта «отрезвляющим примером того, как может работать человеческое стремление к созданию преднамеренно структурированного общества» и может служить примером наиболее поразительного случая «умышленно вызванного, быстрого распада государства во всей человеческой истории» ${ }^{18}$.

Для теоретизации вопроса о национальной конфликтной модели необходимо изменить угол зрения: каков “национальный стиль” развития страны в миросистеме, характеризующийся особенностями режимов и грамматик, жестко или нежестко навязываемых миросистемой правил» ${ }^{19}$, какова природа конфликта постсостояния между воздействием традиций прошлого и их публичным отвержением (Дарендорф).

Эта призма предполагает анализ социальных, психологических, политических механизмов разрешения конфликтов в следующих рамках:

-критерии упорядоченности сочиальных полей конфликта - в социуме либо сформированы устойчивые представления о приемлемом уровне конфликта как продуктивного элемента социального взаимодействия, позволяющего отрефлексировать собственную позицию, оптимизировать конфликтную ситуацию, внести в нее необходимые коррективы, либо отрицается продуктивность конфликта, а признается лишь борьба на уничтожение;

${ }^{16}$ Парсонс T. О структуре социального действия. М.: Академический проект,2000,С.701

17 В терминологии Дэвида Лэндеса «Существуют культуры, которые я называю токсичными... они калечат тех, кто держится за них» (Culture Counts: Financing, Resources, and the Economics of Culture In Sustainable Development // The World Bank. Washington, DC, 2000. P. 30.)

18 Норт Д. Понимание процесса экономических изменений. М.: Изд. дом Гос. ун-та - Высшей школы экономики, 2010,C.23.

${ }^{19}$ Ядов В.А. Современная теоретическая социология как концептуальная база исследования российских трансформаций: Курс лекций для студентов магистратуры по социологии. СПб.: Интерсоцис, 2009,С.83 
-мера антропоцентричности или власте(иерархо)иентричности в способах действий или механизмах разрешения конфликтов. В первой модели данные механизмы определяются институциональной системой «работы» с конфликтом, соизмеримой с человеком и ориентированной на него, в которой решение конфликтных социальных проблем ищут в гражданских сетевых связях, на разных уровнях, в различных точках горизонтальных коммуникаций. Во-второй - коммуникативные конфликтные отношения завязываются на власть, единственным, закрепленным в традициях способом действий является жалоба начальству, а все неразрешенные конфликты иентрируются на вершину управленческой пирамиды, где социальный организм концентрирует конфликты и куда канализируется конфликтная социальная энергия, некомпенсированная, неперекрытая, нецивилизованная. Истина, сила и право в разрешении конфликтов всегда остаются за иерархией, которая является носителем и выразителем идеи целого, всегда стремящегося к снятию конфликта всеми сдерживающими, репрессивными, силовыми способами. В этой парадигме конфликт зачастую разрешается или покупается ценой победы иерархии над здравым смыслом;

- критерии эстетической оформленности конфлик$m a$ - обеспечивает ли стиль разрешения конфликта, выхода из негативной ситуации психологический комфорт, рождает ли чувство защищенности? Перефразируя Олдоса Хаксли, можно сказать, что «главное ведь не в том, чтобы выйти из конфликта, а в том, кем ты выйдешь».

Вполне очевидно, что проекции управления, власти и т.д. в конфликте стремятся к этизации и эстетическому оформлению. Политико-экономический маргинализм к конфликте означал бы утерю «антропологического», т.е. выводил бы конфликт за формат переживаемого социальным субъектом. В этой доминанте редуцирования конфликта к функциональным отношениям институций и субъектов, невозможно достаточно эффективно выстроить политические механизмы и институты, внутриполитический дизайн социального конфликтного поля , поскольку они не будут восприниматься как жизненные, ибо лишаются этического переживания. В пространстве конфликта необходима демонстрация перспективы, невозможная без особой топологической соотнесенности взаимодействия этического и политико-экономического
Такая трактовка выводит исследователя в иную, более широкую, область измерения конфликтных моделей.

Дуглас Норт с соавторами сформулировали адекватный показатель категоризации конфликтных моделей, при котором важно «определить, приводит ли рассеянный контроль над насилием к угрозам его применения, играя центральную роль в социальном порядке, или контроль над насилием консолидирован и поэтому многие отношения осуществляются без угрозы насилия. Порядки ограниченного и открытого доступа коренным образом отличаются друг от друга по отношению к этим измерениям насилия и организации насилия» ${ }^{20}$. Ключевое значение приобретают механизмы разрешения конфликтов, определяющие характер социального, политического, экономического и культурного ландшафта, или иначе говоря, ключевой способ конфликторазрешения в том или ином обществе.

Задача выявления национальной специфики форм и способов разрешения конфликтов и их сочетания не может быть решена без ясно сформулированного понимания того, что любой процесс взаимодействия людей, всегда в какой-то степени отличающихся друг от друга потребностями и возможностями, внешними условия жизнедеятельности, неодинаковыми индивидуальными предпочтениями, всегда будет характеризоваться наличием между ними конфликта. Конфликтное взаимодействие рациональных индивидов (т.е. стремящихся к максимизации степени удовлетворения своих предпочтений), приводит к возникновению необходимости согласования их предпочтений, поскольку достижение такого согласия позволяет снизить издержки конфликта. Конечным результатом процесса согласования конфликтных интересов является создание институтов (действующих и выполняемых правил), устанавливающих определенные рамки или ограничения в отношениях взаимодействующих сторон конфликта и обеспечивающих соблюдение установленных правил взаимодействия. Само общество может быть определено как система институциионально ограниченных конфликтов между людьми.

Социум имеет место только при условии действия определенных правил ( институтов), по ко-

\footnotetext{
${ }^{20}$ Норд Д., Уоллис Д., Вайнгаст Б. Насилие и социальные порядки. Концептуальные рамки для интерпретации письменной истории человечества. М.: Изд.Института Гайдара,2011,c.57.
} 


\section{Политика и общество 6 (102) • 2013}

торым развиваются конфликты, а политический процесс может быть также определен как процесс согласования позиций сторон в конфлик$\boldsymbol{m} \boldsymbol{e}^{21}$. При этом существующая институциональная структура разрешения конфликтов может «загнать» (Дуглас Норт) общество в определенное русло развития. Причины неудач модернизационнных проектов на российском пространстве во многом определены конфигурацией системы институциионального ограничения конфликтов и слабостью «конфликтно-позитивных», консенсусных ценностей и установок в структуре мотивационных характеристик как массового, так и элитарного сознания ${ }^{22}$.

Существенно следующее. Конфликт, как имманентная составляющая социальной жизни, вызывается разными причинами, служит разным целям и реализуется разными средствами, обладает собственной динамикой и не всегда может быть стандартизирован и редуцирован до рутинных правил и процедур. Набирая силу, конфликт может подчинить себе механизмы мотивации и трансформироваться из способа достижения цели в самоцель, затрагивая все чувства и целеполагания, становясь, в терминологии К.Шмитта, экзистенциальной враждой не на жизнь, а на смерть. Для российского политического дискурса вообще характерна метафора « «переднего края» какой-нибудь борьбы, которым в разные времена (в особенности советские, но и в постсоветские тоже) и по разным причинам объяв-

${ }^{21}$ «Политика - это процесс согласования наших предпочтений...» Бьюкенен Дж. Границы свободы. Между анархией и Левиафаном // Бьюкенен Дж. М. Сочинения. М.: Таурус Альфа, 1997. С. 212).

22 Известно умозаключение, приписываемое или казненному в 1740 г. русскому вельможе Артемию Волынскому, или юродивому царя Петра III Тихону: «Нам, русским, хлеба не надобно. Мы друг друга едим и тем сыты бываем».Один из основателей отечественной психиатрии, успешно применявший исторический анализ для составления психологических портретов, П.И. Ковалевский отмечал, что «главное у русских -ссоры, свара и вражда между собой». Концептуальной парадигмой современной отечественной политологии является тезис о российской элите как «террариуме единомышленников». См. напр.работы О.В. Гаман-Голутвиной: 1) Авторитаризм развития или авторитаризм без развития: судьбы модернизации на постсоветском пространстве // Вестник МГИМО Университета, 2010. № 4; 2) Метафизические измерения трансформаций российских элит// Политическая концептология 2012 , № 3. лялись, кажется, все российские регионы, институты и просто области человеческой жизни» ${ }^{23}$.

Рассматривая правила конфликтного взаимодействия в российском институциональном пространстве, еще раз констатируем - такие конфликты не канализируются и не регулируются, а только подавляются или исчерпываются с течением времени.

Проблема заключается в том, что в российском обществе многое сконструировано или на разрывах или на компенсаторной активизации традиционных механизмов и связей. Действие неканализированных конфликтов, выходящих за рамки предсказуемого и регулируемого поведения, сопряженного с минимальными возможными издержками, приобретают ту высшую степень интенсивности, какую могут обрести противоречия и несогласия, которую Шмитт определял как «друг/враг», обессмысливают перемены, демпфируют их, придают им новые ориентиры, «переопределяя» развитие. Существенным образом дополняют и расширяют этот тезис наблюдения Александра Филиппова о современном политическом процессе в России: «Впервые за несколько лет у нас появляются именно публичные политические группы, готовые к экзистенциальному противостоянию. Еще не столь враждебны их действия, еще нет не то что признаков, но и предчувствия гражданской войны. Но уже есть дискурс ненависти, риторика «друг/враг».

Политическое размежевание - и это еще одна важная особенность, о которой следует помнить, - может развиться из любой противоположности религиозной, экономической и даже эстетической. Поводы для размежевания могут быть любой природы. Но при этом само размежевание достигает такой степени интенсивности, что оппоненты или конкуренты становятся именно врагами и под углом зрения смертельной, экзистенциальной вражды видят все остальное. Вражда приобретает собственную динамику, политическое подминает под себя все и высасывает всю энергию из других областей жизни. Тогда государству грозит гражданская война и распад, если только не будет новой консолидации, если не появится новое единство «политического народа», противостоящего другим народам как врагам, но искоренившего вражду внутри себя» ${ }^{24}$.

${ }^{23}$ Kaсnэ С.И. О понятии политической формы.// Полития: Анализ. Хроника. Прогноз, 2012. № 4. С. 11

24 Филиппов А. Политическое и полицейское.//Независимая Газета, 15 февраля,2013. 
Конфликтно-репрессивный тип решения проблемы «свой -чужой», характерный для России, противоположен открытым обществам, типичной характеристикой которых является взаимообусловленность сосуществовании «Я» и «Другого»,выраженное в интерпретации Сартра: «мне нужен другой, чтобы целостно постичь все структуры своего бытия». Тут важно еще раз подчеркнуть: свободные, современные, открытые общества, допуская конфликты, одновременно создают защиту против токсичных конфликтов, угрожающих всеобщему согласию, сводя к минимуму расхождения, затрагивающие основополагающие ценности. Взаимозависимость противоборствующих групп и их пересечения внутри конфликтных обществ, которые служат инструментом для «скрепления социальных систем» посредством взаимной нейтрализации, предотвращают распад по основной линии раскола ${ }^{25}$.

В российской практике реализуется в основном модель использования насилия ради достижения групповых интересов в формате открыто манифистируемой вражды различных социальных групп при осознанном использовании политических технологий интенсификации и эскалации конфликтов, в том числе с использованием приема поисков внутреннего и внешнего врагов. В контексте этой устойчивой тенденции социального развития, политической традиции и политической культуры, возникает эффект преобладания административных методов регулирования конфликтности и доминирование неформальной составляющей институциализации конфликтов.

Точно схватывает суть ведённый А. Фурсовым и Ю. Пивоваровым термин «Русская Система» ${ }^{26}$, ко-

\footnotetext{
${ }^{25}$ Обзор современных исследований по данной проблематике содержится в работах: 1)Торвальд Гран. Идея власти и конфликт ценностей в демократических системах 2) Oдбъёрн Кнутсен; О пересекающихся линиях конфликтов и участии в организациях// Теория и методы в современной политической науке. Первая попытка теоретического синтеза. М.: РОССПЭН, 2009.

${ }^{26}$ Пивоваров Ю.С., Фурсов А.И.. Русская Система и Реформы. - Pro et Contra, 1999.T. 4, № 4. Надо отметить, что сам термин «Русская система»,по мнению значительной части научного сообщества, «вызывает сомнения насчет его научной достоверности. Хотя бы потому, что Россия по своему менталитету - страна принципиально бессистемная. В ней, по выражению Л.Н. Толстого, еще ничего не сложилось и только начинает складываться ...Можно использовать термин «систематическая бессистемность» или метафору бессистемной свалки».Подробно об этой дискуссии см.: Куда
}

торый основан на целостном видении социально-исторических российских реалий. В чем суть концепции(применительно к рассматриваемой нами проблематике)?

Во-первых, «русская история... обладает... одним свойством - константой социального бытия, сохраняемой несмотря на все громадные изменения -Россия не решает своих ключевых вопросов (не находит решения, ключа), а изживает их» ${ }^{27}$. Во-вторых, для России характерна «власть-насилие, власть как насилие, безо всяких там ограничений, «сдержек и противовесов». Это - высшее напряжение, густота, интенсивность подавления, распределения, укрощения и пр. Оно качественно, а не количественно отличается от тех видов власти, с которыми его обычно сравнивают. И в первую очередь от тех, что произрастают на Западе. Там власть, в каких бы формах и обличиях она ни являлась миру, всегда и прежде всего - договор, конвенция, список условий, прав и обязанностей сторон, декларация об ограничениях и т. п. Да, и насилие тоже, но строго обузданное императивом права и рационально дозированным «рассеянием» (распределением)» ${ }^{28}$.

Таким образом, в истории русской системы (а, значит, и в истории «конфликтов российских») нет «даже намеков на договоры и взаимоограничения», для нее не характерны диалог ( по определению А.С.Ахиезера - «В России вместо диалога реализуется совокупность монологов») взаимные уступки и компромиссы.

Данная постановка проблемы выявляет ещё одну призму - силовые линии социального поля (зоны социального пространства, в которых конфликтное взаимодействие принимает особо интенсивный характер), по которым можно оценивать напряженность социума, в российском (и постсоветском) пространстве, быстро проходят некий пороговый уровень и радикально меняют социально-политический ландшафт в считанные дни и даже часы. О том же повествует и Д. Фурман: «Опыт других систем этого “вида” говорит о том, что летальный кризис всегда “подкрадывается незаметно” - его неожиданность имманентна системам, в

ведет кризис культуры? Опыт междисциплинарных диалогов. Под общ. ред. И.М. Клямкина.М.: Новое издательство, 2011,СC.56-117

${ }^{27}$ Пивоваров Ю.С. К вопросу о методологии понимания России // Россия и современный мир. 2011, № 3,С.20

${ }^{28}$ Пивоваров Ю.С. Русская власть и публичная политика. Заметки историка о причинах неудачи демократического транзита. // Полис, 2005,№ 6. 


\section{Политика и общество 6 (102) • 2013}

которых нет обратной связи власти общества, где в избытке поступают сигналы об опасностях не реальных, но не поступают сигналы об опасностях реальных» ${ }^{29}$.

Таким образом, можно отметить, что в России конфликты нередко принимали особенно острый, обвальный, разрушительный, катастрофический характер, ведущий к быстрому и «неожиданному» (революционному, а не эволюционному) слому всех или большей части институтов, в том числе и самого государства.

Морис Палеолог, посол Франции в Петербурге в 1914-1917 гг., артикулировал, что на Западе «самые быстрые и полные изменения связаны с переходными периодами, с возвратом к старому, с постепенными переходами. В России чашка весов не колеблется, она сразу получает движение. Все разом рушится, все образы, помыслы, страсти, идеи, верования, все здание» ${ }^{30}$.

Кризис и распад оказывались зачастую единственным механизмом преобразования России. Четыре отличающихся друг от друга революции за одно столетие, две из которых привели к развалу страны. Императорская власть и мощная бюрократия, имеющие за собой многовековые традицию, перестали существовать за 24 часа в феврале 1917 года. Стремительность произошедшего уже тогда поражала современников. Василий Васильевич Розанов писал: «Русь слиняла в два дня. Самое большое - в три. Даже "Новое время" нельзя было закрыть так скоро, как закрылась Русь. Поразительно, что она разом рассыпалась вся, до подробностей, до частностей. И собственно, подобного потрясения никогда не бывало... Переход в социализм и, значит, в полный атеизм совершился у мужиков, у солдат до того легко, точно в баню сходили и окатились новой водой. Это совершенно точно, это действительность, а не дикий кошмар...Самое разительное и показующее все дело, всю суть его, самая сутенька заключается в том, что ничего в сущности не произошло. Но все рассыпалось» ${ }^{31}$.

Имеющийся опыт анализа свидетельств очевидцев, пораженных видимой легкостью распада теперь уже советского государства в 1991 г., подкрепляет хорошо

29 Фурман Д. Движение по спирали. Политическая система России в ряду других систем. М.: Весь мир. 2010,С.154.

${ }^{30}$ Палеолог М. Царская Россия накануне революции. М.: Политиздат, 1991,С. 57.

${ }^{31}$ Розанов В.В. Апокалипсис наших дней.//Библиотека Вехи. [Электронный pecypc] URL: http://www.vehi.net/rozanov/ apokal.html(дата обращения: 15.10.2012) обоснованный концептуальный вывод Ю.Пивоварова: «русское государство, русская институциональная система, даже русская полицейщина - при всей их грозности, грузности, громадности, при всех страхах, которые они наводили (наводят - это сохранилось) на ближних и дальних, - чрезвычайно неустойчивы, неэластичны, неэффективны, но: хрупки и ненадежны» ${ }^{32}$.

Не останавливаясь более на истории российских кейсов деконструкции и разрушения социума, следует указать на такую специфику конфликтного взаимодействия, как отсутствие социальной динамики в движении от «токсичных» видов социальных конфликтов, не поддающихся институционализации и несущих угрозу существованию общества в сторону по преимуществу «позитивных», не приводящих к разрушению социума, механизмов неконфликтных изменений и конфликтов, поддающихся институционализации.

Изложенная концепция позволяет сделать вывод о том, что о том, что разнообразие существующих в разных странах систем институционализации конфликтов можно представить в виде социальнополитического континуума, отражающего способность соответствующих обществ адаптироваться к конфликтам и даже целенаправленно управлять ими в своих интересах. Проблемы российских трансформаций связаны именно с отсутствием такого политико-социального континуума, при котором конфликты не регулируются рационально, якобы «решаются», а на деле подавляются. Среди причин «структурной неспособности» Германии к демократии, анализируемых Дарендорфом в книге «Общество и демократия в Германии» ${ }^{33}$, ряд положений которой развит и в известном труде «Современный социальный конфликт. Очерк политики свободы» ${ }^{34}$, он особо выделял модернизачионный дефииит, выражавшийся в неспособности разрешать конфликты ненасильственным путем и неспособность элит к конкуренции друг с другом в системе объединяющего разнообразия. Травматологическая метафора П. Штомпки ${ }^{35}$ акцен-

\footnotetext{
32 Пивоваров Ю.С. “...И в развалинах век”//Полис,2011,№6

${ }^{33}$ Dahrendorf $R$. Gesellschaft und Demokratie in Deutschland. Piper, München, 1965.

${ }^{34}$ Дарендорф Р. Современный социальный конфликт. Очерк политики свободы. М.: РОССПЭН , 2002.

${ }^{35}$ Штомпка П. Социальное изменение как травма // Социс. 2001. № 1. С. 6-17; Штомпка П. Культурная травма в посткоммунистическом обществе (статья вторая) // Социс.2001. № 2. C. 3-12.
} 
тирует внимание на признаках дезинтеграции посткоммунистического общества, его системной конфликтности. Операционализируя данный концепт, можно предположить, что существует два типа конфликтного стиля переходного общества. Один, постоянно реконфигурируя конфликты, не допуская острых вспышек, раскручивает спираль социальной реконструкции и приводит к внедрению нового социального комплекса, конфликт «выполняет функции стабилизации и интеграции внутригрупповых отношений. Предоставляя обеим сторонам безотлагательную возможность для прямого выражения противоречащих друг другу требований, такие социальные системы могут изменить свою структуру и элиминировать источник недовольства. Свойственный им плюрализм конфликтных ситуаций позволяет искоренить причины внутреннего разобщения и восстановить социальное единство» ${ }^{36}$.

Другой, выстраивая такую конфигурацию разрешения, вернее подавления, конфликтов, при которой она обеспечивается не в результате интериоризации социальных норм, а насильно, путем вмешательства власти, может положить начало спирали социального разрушения, упадку и полной дезинтеграции общества. По Зигмунду Бауману, общество обречено на умирание, на полный коллапс социально-нормативной системы, если отмирание традиционных институтов не восполняется новыми институтами неформального общения и социального контроля ${ }^{37}$. Такой конфликтный стиль Р.Дарендорф сравнивал со злокачественной опухолью: “Тот, кто умеет справиться с конфликтами путем их признания и регулирования, тот берет под свой контроль ритм истории. Тот, кто упускает такую возможность, получает этот ритм себе в противники" ${ }^{38}$.

Используя в качестве методологического инструментария второй догмат полемики, сформулированный Г. Померанцем ${ }^{39}$, подчеркнем: стиль разрешения конфликтов важнее предмета конфликтов. Предметы меняются, а стиль создает и определяет цивилизованность конфликтной матрицы социума, нормы граж-

\footnotetext{
${ }^{36}$ Там же, С.24

37 Бауман 3. Индивидуализированное общество. М.: Лагос, 2002.

${ }^{38}$ Darendorf $R$. 1969. Society and Democracy in Germany. Garden City, N.Y.: Doubleday,P/140

${ }^{39}$ Померани Г. Догматы полемики и этнический мир. //Звез-
} да», 2003, № 6. данского и политического поведения, культурные практики представления своих позиций и выражения отношения к оппонентам. Разумеется, указанные дуальные оппозиции не бывают выражены в абсолютном виде. Можно говорить лишь об их соотношениях в рамках той или иной политической (в более широком контексте -конфликтологической) культуры по принципу доминанта - компонента.

Исключительно важными в плане анализа российского алгоритма осмысления конфликта и поведения в конфликте, представляются исследования Игоря Яковенко ${ }^{40}$, Льва Гудкова ${ }^{41}$, Николая Розова ${ }^{42}$.

Их инструментарий позволяет «схватить» одновременно эмпирические свидетельства институциональных рамок конфликтных взаимодействий и особенности реальных поведенческих практик. Игнорирование подобных особенностей, например, привело одного из ведущих советников при осуществлении российских реформ Дж. Сакса констатации: «Мы положили больного на операционный стол, вскрыли ему грудную клетку, но у него оказалась другая анатомия» ${ }^{43}$.

Обобщим эти характеристики, показанные в данных фундированных текстах с особым интеллектуальным качеством, оставляя, по-возможности, без изменений авторские изящные формулировки и не перегружая, вместе с тем, изложение обильным цитированием и сносками на конкретные страницы указанных работ.

- $\quad$ стремление к предельному обострению любого конфликта, установка на блокирование диалога с противостоящей стороной в любых его формах. Любые компромиссы нетерпимы и постыдны.

- $\quad$ внеморальность конфликта - правовые и моральные нормы разрешения и урегулирования конфликтов отрицаются при оценке поведения своих» по отношению к противнику. Применительно к противнику, которому приписываются все мыслимые и немыслимые злодеяния, позволено абсолютно все.

40 Яковенко И.Г. Познание России: цивилизационный анализ. М.: РОССПЭН, 2012; Яковенко И.Г., Музыкантский А.И. Манихейство и гностицизм: культурные коды русской цивилизации. М. : Русский путь, 2010

${ }^{41}$ Гудков Л. Негативная идентичность. Статьи 1997-2002 г. М.: Новое литературное обозрение, 2004; Гудков Л.Д. Абортивная модернизация. .:РОССПЭН,2011

${ }^{42}$ Розов Н.С. Колея и перевал: макросоциологические основания стратегий России в XXI веке

${ }^{43}$ Sachs J.D. What Went Wrong in Russia // New Perspectives Quarterly. 1999. Vol. 16. Iss. 1 (Winter). P. 31-32 


\section{Политика и общество 6 (102) • 2013}

- агрессивно-наступательная стилистика разрешения конфликта в сочетании с непременной профанацией актуального и потенциального противника и апелляцией не к противной стороне, а к внешнему наблюдателю, которому пытаются продемонстрировать собственную правоверность. Это «стилистика скандала на одесском Привозе со специфически базарным криком, задиранием подола и плевками в лицо» ${ }^{44}$, маркирующая неприятие альтернативной мировоззренческой позиции.

- отсутствие «рыцарского этоса» в отношениях к противнику, т.е. системы представлений, базирующихся на фундаментальном убеждении в онтологическом равенстве противников, обладающих равным достоинством и наделенных той же человеческой природой.

- $\quad$ гипертрофированная степень толерантности к рисковым формам поведения

- $\quad$ последовательное упрощение и примитивизация причин конфликтов, их редуцирование до уровня бинарной оппозиции с соответствующими технологиями предупреждения и разрешения.

- ограниченность «вещественного измерения» коммуникации в конфликте темой ${ }^{45}$ своих и чужих, $u x$ отчуждение, готовность к взаимному насильственному подавлению, преимущественно принудительные формы урегулирования конфликтов в установках сознания и поведения с постоянно присутствующей угрозой легитимированного государством насилия

- использование « высших ценностей» (Святая Русь, Правда, Служение Великой России и т.д.) для оправдания насильственного вмешательства государства и его представителей в приватную сферу конфликтов, стремление «учить людей жизни» принятием все новых и новых законов и правил, регламентирующих поведение

- чрезмерная «идейность» конфликта - самоутверждения через принижение символов (идеалов, ценностей, исторических персонажей, политических деятелей), священных, значимых для сторон конфликта.

\footnotetext{
${ }^{44}$ Яковенко И.Г., Музыкантский А.И. Манихейство и гностицизм: культурные коды русской цивилизации. М.: Русский путь, 2010

${ }^{45}$ По Луману, тема, как последовательный процесс примыкающих друг к другу операций,определяет смысловые границы коммуникации.
}

- $\quad$ иерархичность конфликта - взаимное неприятие стиля и манер поведения, знаков уровня потребления между представителями разных по статусу и доходам сословий.

- иррациональность методов регулирования конфликтов и снижения социальной напряженности, амбивалентная архитектура сочетания реалистических и нереалистических конфликтов, ${ }^{46}$ их диффузия, превращение конфликта как средства цели в конфликт как самоцель, сознательной поиск внутренних и внешних врагов, эскалация и раздувание мнимых конфликтов.

Суммируя вышесказанное, приходится констатировать, что реализовать в рамках данной модели требования к заинтересованности всех акторов конфликтного процесса в установлении общих правилах игры, признания их взаимной необходимости и ценности практически невозможно.

Сергей Цирель предложил концептуальный инструментарий анализа холодных и теплых обществ , который исходит из того, что оппозиция Запад vs Вocток характеризует в первую очередь тип институтов, а оппозиция «холодные общества» vs «теплые общества» - количество институтов и их устойчивость. Многочисленные формы расколов и противостояний есть следствие чрезмерного разнообразия на низших уровнях иерархии, препятствующее разнообразию на верхних уровнях иерархии и формированию действенных институтов ${ }^{47}$. Базовые суперпозиции построения институциональной модели полей конфликта носят для культурно-исторических традиции «холодных» или «теплых» обществ парадигматический характер. Корневое различие состоит в том, что для «холодной» модели в характерна медиативная структура, тогда как для «теплой» - дуалистическая. При доминанте дуалистического принципа стороны конфликта стремятся к максимальной партисипации, т.е. к экзистенциальному отнесению к одному из полюсов, при максимальном взаимоотчуждении. Субъекты конфликтного взаимодействия предельно герметизированы. Односторонняя партисипационная направленность порождает симметричные негативные действия.

46 Козер Л. Функции социального конфликта. М.: ИдеяПресс, Дом интеллектуальной книги, 2000, СС. 71-79.

${ }^{47}$ Цирель С.В. «QWERTY-эффекты», «PATH DEPENDENCE» и закон Серова или возможно ли выращивание устойчивых институтов в России//Экономический вестник Ростовского Государственного университета.2005,том 3,№3,c.44-57. 
Конфликт перестаёт адекватно описываться, начинает «разбухать», его содержательные и позитивные значения нерефлективно поглощаются негативными смыслами и коннотациями. Поле конфликта «разворачивается» сверх меры, сохраняющей необходимый уровень стабильности социума, место конструктивных противоречий занимают противоречия деструктивные, «перетягивание каната» закрывает возможность для социальной динамики. Происходит деэтизация, деэстизация и «раскультуривание» конфликта.

В отличие от этой парадигмы, моделирующей динамику конфликтов в закрытой системе и стремящегося максимально блокировать диалоговую составляющую, медиативная структура предполагает принцип открытости конфликта, динамичное взаимодействие в реальном снятии конфликтной оппозициионности. Это - наиболее продуктивная форма конфликтного процесса.

В России же, похоже, на стратегическом уровне политической рефлексии крайние, предельные формы конфликта (мантры об исчерпанности лимита революций или о российском бунте - « бессмысленном и беспощадном») как бы запланированы и только ждут своей реализации при определенных условиях в политической практике. Конфликт редуцируется до разнообразных политических и социологических спекуляций об особенностях повседневного поведения или политического языка его субъектов.

\section{Библиография:}

1. Ахиезер А.С. Социокультурная динамика России. Том 2. Социокультурный словарь. Новосибирск: Сибирский хронограф, 1998

2. Бердяев Н.А.Судьба России.М.:АСТ,2010

3. Дарендорф Р. Современный социальный конфликт. Очерк политики свободы. М.: РОССПЭН, 2002

4. Ильин В.В., Панарин А.С., Ахиезер А.С. Теоретическая политология: Реформы и контрреформы в России. Циклы модернизационного процесса М.: Изд-во МГУ, 1996.

5. Кантор К.М. Двойная спираль истории: Историософия проектизма. Т.1: Общие проблемы. М.: Языки славянской культуры,2002

6. Козер Л. Функции социального конфликта. М.: Идея-Пресс, Дом интеллектуальной книги, 2000
7. Куда ведет кризис культуры? Опыт междисциплинарных диалогов. Под общ. ред. И.М. Клямкина. М.: Новое издательство, 2011

8. Миронов Б.Н. Русские революции начала XX века: уроки для настоящего // Полис. 2011. №5.

9. Парсонс Т. О структуре социального действия. М.: Академический проект,2000

10. Парсонс Т. О социальных системах. М.: Академический проект, 2002

11. Пивоваров Ю.С. К вопросу о методологии понимания России // Россия и современный мир. 2011, № 3

12. Пивоваров Ю.С. “...И в развалинах век”// Полис, 2011, №6

13. Розов Н.С. Колея и перевал: макросоциологические основания стратегий России в XXI веке. М.: РОССПЭН, 2011

14. Филиппов А.Политическое и полицейское.//Независимая Газета, 15 февраля,2013.

15. Фурман Д. Движение по спирали. Политическая система России в ряду других систем. М.: Весь мир. 2010

16. Цирель С.B. «QWERTY-эффекты», «РАTH DEPENDENCE» и закон Серова или возможно ли выращивание устойчивых институтов в России// Экономический вестник Ростовского Государственного университета. 2005, том 3, №3, с.44-57.

17. Яковенко И.Г. Познание России: цивилизационный анализ. М.:РОССПЭН, 2012.

18. Яковенко И.Г., Музыкантский А.И. Манихейство и гностицизм: культурные коды русской цивилизации. - М. : Русский путь, 2010

\section{References (transliteration):}

1. Ahiezer A.S. Sociokul'turnaya dinamika Rossii. Tom 2. Sociokul'turnyy slovar'. Novosibirsk: Sibirskiy hronograf, 1998

2. Berdyaev N.A. Sud'ba Rossii.M.:AST,2010

3. Darendorf R. Sovremennyy social'nyy konflikt. Ocherk politiki svobody. M.: ROSSPEN , 2002

4. Il'in V.V., Panarin A.S., Ahiezer A.S. Teoreticheskaya politologiya: Reformy i kontrreformy v Rossii. Cikly modernizacionnogo processa M.: Izd-vo MGU, 1996.

5. Kantor K.M. Dvoynaya spiral' istorii: Istoriosofiya proektizma. T.1: Obschie problemy. M.: Yazyki slavyanskoy kul'tury,2002 


\section{Политика и общество 6 (102) • 2013}

6. Kozer L. Funkcii social'nogo konflikta. M.: IdeyaPress, Dom intellektual'noy knigi,2000

7. Kuda vedet krizis kul'tury? Opyt mezhdisciplinarnyh dialogov. Pod obsch. red. I.M. Klyamkina. M.: Novoe izdatel'stvo, 2011

8. Mironov B.N. Russkie revolyucii nachala HH veka: uroki dlya nastoyaschego // Polis. 2011. №5.

9. Parsons T. O strukture social'nogo deystviya. M.: Akademicheskiy proekt,2000

10. Parsons T. O social'nyh sistemah. M.: Akademicheskiy proekt, 2002

11. Pivovarov Yu.S. K voprosu o metodologii ponimaniya Rossii // Rossiya i sovremennyy mir. 2011, № 3

12. Pivovarov Yu.S. “...I v razvalinah vek"//Polis, 2011, №6
13. Rozov N.S. Koleya i pereval: makrosociologicheskie osnovaniya strategiy Rossii v XXI veke. M.: ROSSPEN, 2011

14. Filippov A. Politicheskoe i policeyskoe.//Nezavisimaya Gazeta,15 fevralya,2013.

15. Furman D. Dvizhenie po spirali. Politicheskaya sistema Rossii v ryadu drugih sistem. M.: Ves' mir. 2010

16. Cirel' S.V. «QWERTY-effekty», «PATH DEPENDENCE» i zakon Serova ili vozmozhno li vyraschivanie ustoychivyh institutov v Rossii//Ekonomicheskiy vestnik Rostovskogo Gosudarstvennogo universiteta.2005, tom 3,№3,s.44-57.

17. Yakovenko I.G. Poznanie Rossii: civilizacionnyy analiz.M.:ROSSPEN,2012.

18. Yakovenko I.G., Muzykantskiy A.I.Maniheystvo i gnosticizm: kul'turnye kody russkoy civilizacii. M. : Russkiy put', 2010 